\title{
JUURNAL_RU
}

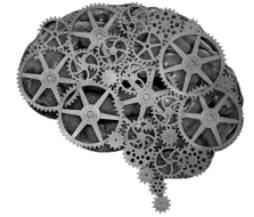

COMPANY GROUP "INTELLEKT"

\author{
Данилина И.В. \\ Кубанский государственный аграрный университет \\ Краснодар, Россия
}

doi: 10.18411/lj2016-3-51

\section{Институционализация целевых программ в системе местного самоуправления}

Социальные институты - лежат в основе категориальных моделей социологии. Их столько, сколько имеется автономных механизмов для реализации распределительных отношений. Они важны для индивида с позиции собственного биологического воспроизводства, а для общества - с позиции социализации индивида или же достижения обществом своей максимальной духовности. [9].

Их непрерывное развитие, трансформация, онтогенетические процессы объясняются непрерывным развитием общества и сопутствующих этому явлений.

Любой социальный институт, по логике Шереги Ф.Э. (и с этим нельзя не согласиться) функционирует с учетом интересов капитала, т.е. в целях его накопления. Причём под капиталом он подразумевает не просто деньги, а всю систему производственно-распределительных отношений, способных стимулировать дальнейшее развитие цивилизации. Выходит, что «накопление капитала» для социального института - есть накопление опыта, связей, моделей и совершенствующихся структур, «обкатка» и наработка нового, выявление иных рациональных возможностей, и т.д.

В современном словаре иностранных слов, «институционализация - это учреждение каких-либо новых социальных институтов, правовое и 
организационное закрепление тех или иных общественных отношений» [4], институциональный — это «связанный с социальными институтами, имеющий отношение к ним». Социальные связи, лежащие в основе социальных институтов, называются институциональными [3], а сам процесс придания этим связям упорядоченного, нормативного характера именуется институционализацией. Данные понятия важны для понимания того, что существующие социальные институты не есть что-то один раз заданное и неизменное, изменения, происходящие в обществе, неизбежно ведут как к их модификации, так и к возникновению новых социальных институтов и институциональных форм. [6]

Следует признать, что в эпоху социальных потрясений институциональная система общества утрачивает свою функциональную эффективность и формируется потребность в ее обновлении. [1]

Направленность институциональных преобразований и формы их реализации определяются той социально-экономической средой, в которой они осуществляются, и результатами, которые необходимо достичь.

В современной России в общих чертах сформирован правовой институт, местного самоуправления и для муниципальных образований появилась возможность заниматься собственным экономическим развитием. В процессе решения задач муниципального образования на первый план, выходит проблема внедрения и распространения на муниципальном уровне новых методов управления, выработанных органами местного самоуправления и не только одобренных населением, но и позволяющих населению участвовать в процессах местного самоуправления. В частности, в формировании и реализации федеральных, региональных и муниципальных целевых программ, решающих бесчисленные проблемы - от финансирования различного рода общественных инициатив до укрепления материально-технической базы учреждений. Предпосылки и условия возникновения этих программ являются следствием 
исторического развития политического и общественного диалога власти и общества.

Для России и её граждан, ведущих диалог с властью ради достижения более лучшего качества жизни, такие программы, в качестве самостоятельных институтов помогают вывести общество на качественно новый уровень жизни, укоренить его идеологическую и укрепить материальные опоры, принимая во внимание закономерности и особенности его исторического развития. Можно ли эти процессы, сопряжённые с определёнными социальными действиями, основанными на существовании реальных проблем, решение которых с течением времени приобретает очерченные узнаваемые рамки, приносит видимые результаты, -рассматривать с точки зрения функционирования полноправного социального института? Или процесс институционализации ещё не завершён, но мы явно можем наблюдать его рождение?

Рассматривая проблему институционализации государственных, региональных и муниципальных целевых программ, необходимо понимать, что над каждой такой программой работают специалисты различных отраслей и направлений деятельности. Поэтому и социологам, и политикам, и управленцам, и экономистам в работе над такими программами желательно учитывать причинно-следственные предпосылки возникновения социальных институтов вообще, владеть методологическим аппаратом социологических исследований, уметь формулировать результаты своих наблюдений в хронологический ряд проблем и закономерностей для их дальнейшего рассмотрения и решения.

Современный российский учёный А.В. Зайцев [2] на основании своих наблюдений и исследованиях ряда других российских и зарубежных учёных сформулировал и сделал научное описание процесса институционализации диалога государства и гражданского общества. Фактически, опыт показывает, что возникновение явления реализации целевых программ обязано становлению именно этого института нашего общества - института диалога государства и гражданского общества. Потому что именно в результате диалога рождаются 
запрашиваемые обществом задачи, которые оно ставит перед государством, и которые государство уполномочено решать через систему местного самоуправления. А органы местного самоуправления, в силу возложенных на них функций и полномочий, обязаны решать вопросы местного значения, к которым относятся вопросы непосредственного обеспечения жизнедеятельности и качества жизни населения муниципального образования, и затрагивает интересы каждого гражданина.

Обычно, такие вопросы рождаются во время сходов граждан, которые являются одной из форм непосредственного участия жителей в обсуждении и решении вопросов местного значения. Альтернативой схода граждан может быть встреча с населением по месту жительства, как форма диалога кандидата в депутаты с избирателями. Отличие состоит в том, что сход граждан организуется и планируется действующими органами исполнительной власти, и ими могут быть привлечены для участия и решения вопросов местного значения руководители градообразующих и жизнеобеспечивающих структур, руководители учреждений, а также избранные депутаты городской Думы или (и) Законодательного собрания. При таком широком представительстве уполномоченных лиц и руководителей в администрациях созданы и работают специальные регламенты организации подобных совещаний, позволяющие вести подробный протокол, учёт и контроль данных поручений. Для систематизации обращений граждан к органам исполнительной и представительской власти в регионах и городах России введена практика формирования программы «Наказы избирателей», на примере которой мы предлагаем рассматривать целевые программы, как социальный институт в системе органов местного самоуправления.

Считается, что социальные институты возникли в связи с объективной потребностью общества в специальном регулировании в сферах социальных отношений и социальной деятельности. 
Подробно процесс институционализации,.т.е. образование социального института, рассмотрен С.С.Фроловым. [8]

В таблице 1 отражены основные этапы формирования и реализации института «Наказов избирателей», отражающие классические этапы процесса институционализации.

Таблица 1

\section{Этапы процесса институционализации (по С.С. Фролову) в проекции на функционирование муниципальной программы «Наказы избирателей»:}

\begin{tabular}{|c|c|c|}
\hline $\mathbf{N}$ & $\begin{array}{c}\text { Наименование этапа институционализации } \\
\text { (по С.С. Фролову) }\end{array}$ & $\begin{array}{c}\text { Характеристика этапа } \\
\text { института «Наказы избирателей» }\end{array}$ \\
\hline 1 & $\begin{array}{l}\text { Возникновение потребности, } \\
\text { которой тровлетворение } \\
\text { действий; }\end{array}$ & $\begin{array}{l}\text { Потребность решения вопросов местного } \\
\text { значения, затрагивающих жизнедеятельность } \\
\text { населения }\end{array}$ \\
\hline 2 & Формирование & 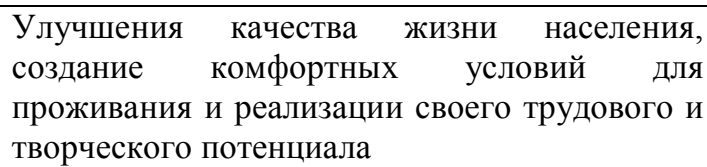 \\
\hline 3 & $\begin{array}{lcccc}\text { Появление } & \text { социальных норм } \\
\text { стихийного } & \text { социального } & \text { взавил в ходе } \\
\text { осуществляемого } & \text { методом } & \text { проб и и ойствия, }\end{array}$ & $\begin{array}{l}\text { Работа приёмных по обращению граждан; } \\
\text { Организация сходов граждан; } \\
\text { Организация встреч органов исполнительной } \\
\text { и представительской власти с населением }\end{array}$ \\
\hline 4 & $\begin{array}{l}\text { Появление процедур, связанных с нормами и } \\
\text { правилами; }\end{array}$ & 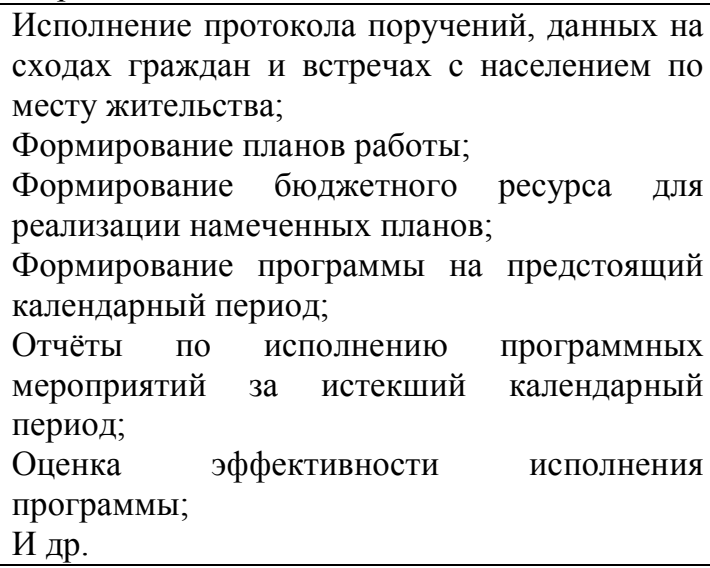 \\
\hline 5 & $\begin{array}{l}\text { Институционализация норм и правил, процедур, } \\
\text { Т.е. их принятие, практическое применение; }\end{array}$ & $\begin{array}{l}\text { Работа в соответствие с принятой программой } \\
\text { управлений } \\
\text { функциональных и территориальных органов } \\
\text { исполнительной } \quad \text { власти; появление } \\
\text { дополнительных должностных обязанностей; }\end{array}$ \\
\hline 6 & 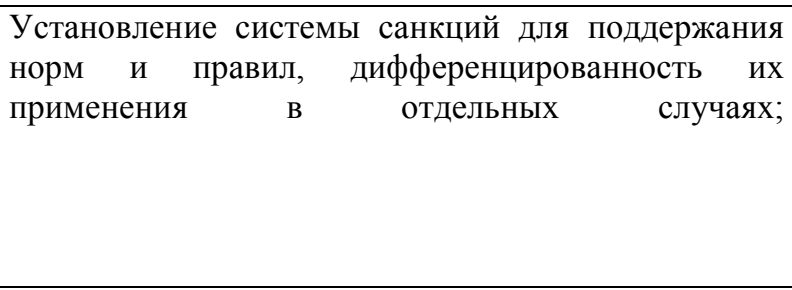 & $\begin{array}{l}\text { Определён период и форма отчётности по } \\
\text { выполнению программных мероприятий } \\
\text { Определён период и форма контроля } \\
\text { выполнения мероприятий; } \\
\text { Определён порядок обращения граждан к } \\
\text { органам исплнительной и представительской } \\
\text { власти; }\end{array}$ \\
\hline 7 & \begin{tabular}{crcrr} 
Создание системы & \multicolumn{2}{c}{ статусов } & и & ролей, \\
охватывающих всех & без исключения & членов \\
института». & {$[2]$} & & \\
\end{tabular} & $\begin{array}{l}\text { Закон краснодарского края «О } \text { наказах } \\
\text { избирателей». }\end{array}$ \\
\hline
\end{tabular}


Каждый институт, то есть организованный тип деятельности, обладает определенной структурой. «Для того, - пишут В.Г. Марача и А.А. Матюхин [5], - чтобы представить социокультурный институт (...), необходимо различать следующие компоненты его состава (см. ниже схему): институциональную форму (включающую институциональную Идею, слой ее символического закрепления и набор формальных мест, связанных процедурой или процедурами - три верхних элемента схемы), а также материальные и духовные опоры (на схеме обозначены буквами «М» и «Д» соответственно). Существование институциональных опор образует основу стабильности института, которая позволяет ему выполнять функции обеспечения устойчивости общества и стабилизации социальной динамики. Наличие у института духовных опор подразумевает укоренённость института в духе народа, традициях и т. д., безусловную приемлемость его институциональной формы с точки зрения "нравов" данного народа в данную эпоху»

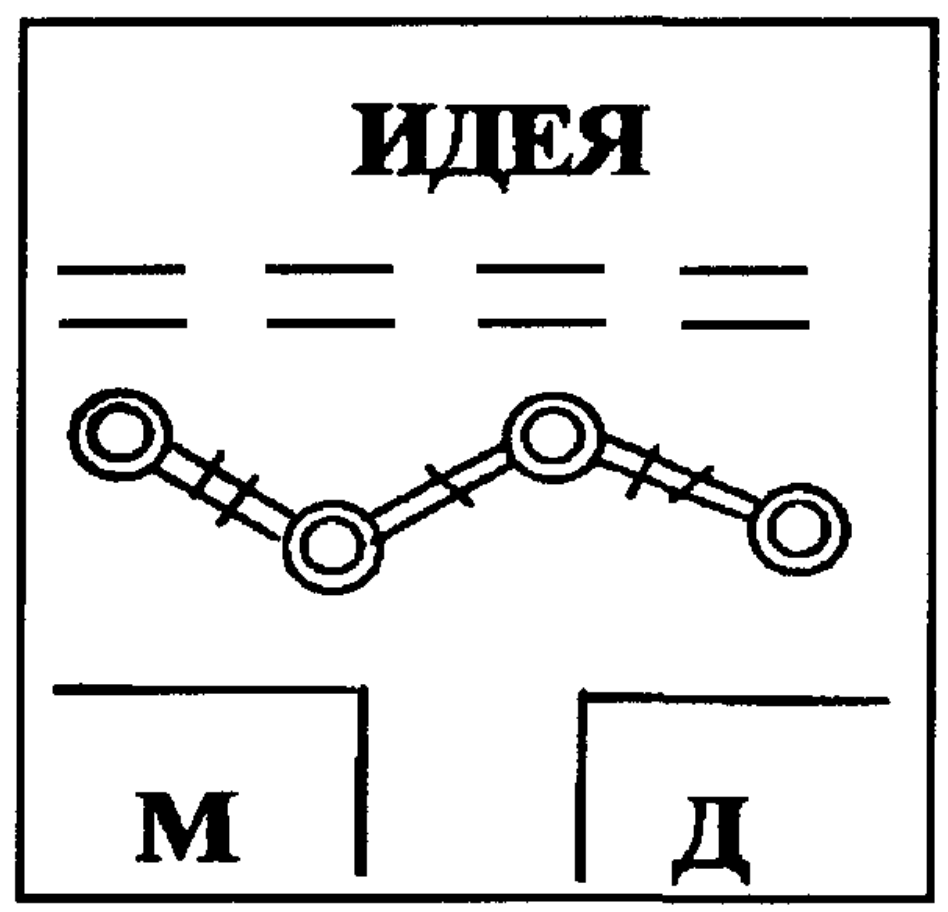

С этой точки зрения институт «Наказы избирателей» можно рассматривать как систему, в основе которой лежат материальные и духовные опоры в качестве намерений исполнительной и представительской власти сохранить такие 
важнейшие составляющие их деятельности, как доверие населения к действующей власти, стремление поддержания традиций открытого диалога администрации и депутатов с населением, а так же поддержание имиджа и статуса города, на территории которого реализуется программа.

Используя методы наблюдения, сравнения, обобщения (индуктивный и дедуктивный методы) и теоретического анализа отдельных сторон, признаков и особенностей объекта исследования - муниципальной целевой программы «Наказы избирателей» (г. Краснодар), автор делает следующие первичные выводы:

1. В системе местного самоуправления функционирование института муниципальных программ может быть затруднено по причине ряда проблем взаимодействия с органами государственной власти (Органами государственной власти не достаточно ведётся разъяснительно-методическая работа при делегировании полномочий федерального значения органам МСУ) и с органами территориального общественного самоуправления.

2. Однополярность выстроенной системы территориального общественного самоуправления не позволяет отслеживать наказы (проблемы), выполняемые (решаемые) депутатами других партий.

3. Отсутствие конкретной общепринятой методологии и установленных критериев оценки эффективности (социальной и экономической) исполненных мероприятий, включённых в целевую программу.

4. Отсутствие организации, способной провести объективную оценку эффективности с учётом общественного мнения и применением других инструментов социометрики.

5. Отсутствие необходимых нормативных законодательных актов, регламентирующих включение в программу мероприятий в пропорциональном соотношении от кандидатов (действующих депутатов) различной партийной принадлежности. 
По результатам наблюдения и анализа функционирования института наказов избирателей, представляется возможным проследить закономерности в исполнении других целевых программ, включая федеральные, региональные и муниципальные. Однако, с учётом противоречий, рождающихся в гонке за капиталом, институциональные опоры (материальные и духовные) не успевают укорениться в матрице, претерпевая категориальные дополнения. Эти изменения порождают необходимость перестройки внутренних отношений и связей и становятся предметами изучения новых моделей взаимодействия между органами законодательной и исполнительной власти всех уровней и населения.

$\mathrm{C}$ точки зрения реализации функции обеспечения устойчивости общества и стабилизации социальной динамики, изучение процессов институционализации целевых программ уже сегодня позволяет на вербальном уровне выстроить категориальный аппарат и спрогнозировать процессы прогресса либо регресса в шкале развития отношений социума и органов власти. 


\section{Литература:}

1. Жапуев 3.А./«Историческая и социально-образовательная мысль» 2013. № 1

2. Зайцев А. В./ Институционализация диалога государства и гражданского общества: компаративный анализ / Кострома КГУ им. Н. А. Некрасова 2014/ 2014. - 446 c.

3. Кравченко С.А./Учебный социологический словарь / Рос. о-во социологов ; МГИМО(У) МИД РФ ; общ. ред. С.А. Кравченко. - 2-е изд., перераб. и доп. - М. : Анкил, 1997. - 176 с.

4. Крысин Л. П./Современный словарь иностранных слов. // М.: АСТ-ПРЕСС КНИГА, 2012. - 416 с.

5. Марача В.Г., Матюхин А.А. /Методологические проблемы изучения и формирования политико-правового пространства. //[электронный ресурс]: информационный сервер. http://www.fondgp.ru/lib/mmk/37

6. Новикова С.С./Социология и институционализация в России /M.: Московский психолого-социальный институт; Воронеж: Издательство НПО «МОДЭК», 2000. - 464 с.

7. Розин В.М./ Становление и особенности социальных институтов: Культурно-исторический и методологический анализ. М.:2014. - 160 с.

8. Фролов С.С. / Социология. Учебник для высших учебных заведений //Фролов С.С. -М.: Наука, 194с.

9. Шереги Ф. Э. / «Категориальные модели в социологии», Мониторинг общественного мнения, журнал, №5, с. 105, сентябрь-октябрь 2011 г., федеральный образовательный портал «Экономика. Социология. Менеджмент» //http://cyberleninka.ru/article/n/kategorialnye-modeli-vsotsiologii 